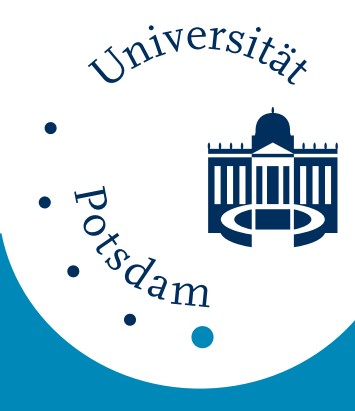

Universität Potsdam

Helmut Elsenbeer, Daniel Lorieri, Mike Bonell

\title{
Mixing model approaches to estimate storm flow sources in an overland flow-dominated tropical rain forest catchment
}

first published in:

Water Resources Research. - 31 (1995), 9, p. 2267 -2278

ISSN: 0043-1397

Postprint published at the institutional repository of Potsdam University:

In: Postprints der Universität Potsdam :

Mathematisch-Naturwissenschaftliche Reihe ; 48

http://opus.kobv.de/ubp/volltexte/2008/1694/

http://nbn-resolving.de/urn:nbn:de:kobv:517-opus-16948

Postprints der Universität Potsdam

Mathematisch-Naturwissenschaftliche Reihe ; 48 


\title{
Mixing model approaches to estimate storm flow sources in an overland flow-dominated tropical rain forest catchment
}

\author{
Helmut Elsenbeer and Daniel Lorieri \\ Institute of Geography, University of Berne, Berne, Switzerland \\ Mike Bonell ${ }^{1}$ \\ Humid Tropics Program, UNESCO, Paris
}

\begin{abstract}
Previous hydrometric studies demonstrated the prevalence of overland flow as a hydrological pathway in the tropical rain forest catchment of South Creek, northeast Queensland. The purpose of this study was to consider this information in a mixing analysis with the aim of identifying sources of, and of estimating their contribution to, storm flow during two events in February 1993. K and acid-neutralizing capacity (ANC) were used as tracers because they provided the best separation of the potential sources, saturation overland flow, soil water from depths of $0.3,0.6$, and $1.2 \mathrm{~m}$, and hillslope groundwater in a two-dimensional mixing plot. It was necessary to distinguish between saturation overland flow, generated at the soil surface and following unchanneled pathways, and overland flow in incised pathways. This latter type of overland flow was a mixture of saturation overland flow (event water) with high concentrations of $\mathrm{K}$ and a low ANC, soil water (preevent water) with low concentrations of $\mathrm{K}$ and a low ANC, and groundwater (preevent water) with low concentrations of $\mathrm{K}$ and a high ANC. The same sources explained the streamwater chemistry during the two events with strongly differing rainfall and antecedent moisture conditions. The contribution of saturation overland flow dominated the storm flow during the first, high-intensity, 178-mm event, while the contribution of soil water reached $50 \%$ during peak flow of the second, low-intensity, 44$\mathrm{mm}$ event 5 days later. This latter result is remarkably similar to soil water contributions to storm flow in mountainous forested catchments of the southeastern United States. In terms of event and preevent water the storm flow hydrograph of the high-intensity event is dominated by event water and that of the low-intensity event by preevent water. This study highlights the problems of applying mixing analyses to overland flow-dominated catchments and soil environments with a poorly developed vertical chemical zonation and emphasizes the need for independent hydrometric information for a complete characterization of watershed hydrology and chemistry.
\end{abstract}

\section{Introduction}

The analysis of storm flow chemical patterns has become a popular tool to infer flow path contributions or preevent and event water components. The basic technique, introduced by Pinder and Jones [1969], consists of a hydrograph separation based on a mass balance approach. Their original twocomponent model, one preevent-water and one event water component, has been applied widely [e.g., Hooper and Shoemaker, 1986; Caine, 1989; Wels et al., 1991; Hendershot et al., 1992; Pionke et al., 1993]; it has been expanded to three components in cases where either the discharge of one of the components was known [DeWalle et al., 1988] or two tracers were used simultaneously [Genereux et al., 1993; Hinton et al., 1994]. The usefulness of this mass balance approach to predict preevent and event water components hinges critically on the assumption that the selected tracers behave conservatively

\footnotetext{
${ }^{1}$ Previously at the Department of Geography, James Cook University of North Queensland, Townsville, Australia.

Copyright 1995 by the American Geophysical Union.

Paper number 95WR01651.

0043-1397/95/95WR-01651\$05.00
}

(i.e., do not participate in any chemical reactions along their flow paths). This type of hydrograph separation into two or three components identifies sources of preevent and event water; it does not identify mechanisms of runoff generation.

More recently, Christophersen et al. [1990] and Hooper et al. [1990] introduced a new technique to predict proportions of contributing sources; it assumes that streamwater chemistry of some catchments is determined by a mixture of subsurface sources, such as groundwater and soil water from various depths. These sources are called end-members because their chemical compositions constitute the extremes of possible stream water observations. Their technique capitalizes on the fact that a vertical chemical zonation, from litter layer to bedrock, exists in many geoecosystems; it is known as end-member mixing analysis (EMMA). In contrast to the mass balance approach, EMMA relies on the solution of a constrained linear least squares estimation problem [Christophersen et al., 1990]; the two approaches share the assumption concerning the conservative nature of the selected tracers, and neither implies a particular runoff process. Their application does not require explicit knowledge of hydrological pathways, but the results of the two approaches may, in turn, provide information about such pathways. If the chemical behavior of selected tracer is 
known, streamwater chemistry can be coupled with catchment hydrology [Beck et al., 1990; Christophersen et al., 1993] to produce a complete picture of watershed chemistry. The reverse approach involves a hydrological study to determine pathways directly from which streamwater chemistry is inferred.

The objective of this paper is to explore the application of mixing models to a catchment in which overland flow was previously identified as an important hydrological pathway. Given this knowledge, we investigate to what extent overland flow may be regarded as a source of storm flow, but we also examine the chemical nature of overland flow in an attempt to identify its end-members. On the basis of this analysis, we then estimate the contributions of "true" sources of storm flow and express these in terms of event and preevent water. Finally, we highlight the problems of applying mixing models to fast flow path-dominated catchments.

\section{Terminology}

"Overland flow" as used in this paper is best defined by Emmett [1978, p. 146]: "... overland flow is defined as the flow of water over the land surface toward a stream channel...", and best described by Moore and Foster [1990, p. 215]: "... overland flow can occur over large parts of the landscape... The flow may be laminar or fully turbulent, and it can exist as broad sheet flow or as flow in microchannels such as rills and ephemeral gullies...." We have nothing to add to the definition and description, but we wish to emphasize what the term does not imply: It does not imply a particular generating mechanism. Whenever we wish to draw attention to the generating mechanism, we add the modifier "saturation," short for "saturation excess." Nor should overland flow be equated tacitly with sheet flow. The terms "end-member," "component," and "source" are interchangeable.

\section{Background}

Apart from their mathematical differences, both mixing models share several assumptions. These may be listed as follows:

1. Tracers do not participate in chemical reactions. EMMA provides a graphical technique (see below) for rejecting the assumption of conservative mixing, but it cannot validate conservative mixing [Christophersen et al., 1990].

2. The tracer concentrations of the postulated storm flow sources must be different.

3. The tracer concentrations of the postulated endmembers or components do not change during events, and their spatial variability is small compared to the differences between end-members or components. The validity of the temporal invariance assumption obviously depends on event duration: If it is in the range of hours [e.g., Pionke et al., 1993; Hinton et al., 1994], this assumption is more likely to hold than if it is in the range of days [Mulholland, 1993] or weeks [e.g., Hendershot et al., 1992]. It also depends on the choice of sources. A shallow soil source influenced by rapid macropore flow from the soil surface is unlikely to meet the temporal invariance assumption regardless of event duration; the possibility of a time-dependent end-member composition has already been anticipated by Christophersen et al. [1990, p. 314].

This last example highlights the importance of end-member selection. Without a priori information about hydrological flow paths, the selection is either arbitrary [Hooper et al., 1990], or depends on pedological information [Christophersen et al., 1990]. If flow path information is available, the "correct" sources are used to begin with, in which case EMMA serves as a validation [Mulholland, 1993]. The mixing plots, a critical tool in EMMA, help to evaluate the selection.

Most applications of mixing models used three sources that were not necessarily identified with preevent or event water. For the Birkenes catchment [Christophersen et al., 1990], a valley bottom and two soil water end-members encompassed stream water observations if inorganic aluminum and hydrogen were used as tracers. For the Panola catchment [Hooper et al., 1990], a combination of floodplain groundwater, hillslope groundwater, and shallow soil water end-members explained most of the variance in stream water concentrations for calcium, silica, magnesium, and alkalinity. For Walker Branch, three end-members, namely, vadose zone, saturated soil zone, and bedrock zone, determined stream water chemistry [ $\mathrm{Mul}$ holland, 1993]; the same sources were identified by a mass balance approach based on radon 222 and calcium [Genereux et al., 1993]. For the Harp 4-21 catchment, Hinton et al. [1994] singled out a preevent till water, a preevent soil water, and an event soil water component, using silica and oxygen 18 . For the Fish Run catchment, two preevent water components, groundwater and soil water, and an event water component, channel precipitation, were identified based on oxygen 18 [DeWalle et $a l ., 1988\}$. A three-component model for Shaver Hollow [Bazemore et al., 1994] distinguished between preevent soil water and preevent groundwater in addition to precipitation and throughfall as event water; the tracers were chloride and oxygen 18 .

The reluctance to label sources as preevent and event water may be partly due to the lack of independent hydrological information about flow paths (an exception is Walker Branch [Wilson et al., 1990, 1991]) and partly due to the ambiguous relationship between flow paths and relative age of water: While it is obvious that event water reaches a stream by fast pathways, such as overland flow, preevent water may follow fast or slow pathways [McDonnell, 1990]. We contend that only a combined hydrologic-hydrochemical approach adequately addresses the issue of pathways versus preevent and event water; the stream water chemical signal alone does not in all cases contain all the hydrological information.

Except for Walker Branch, all catchments to which mixing models were applied share one essential feature: Fast flow paths in general and overland flow in particular were either irrelevant or not documented, though their existence was postulated for Shaver Hollow. Quite in contrast, a detailed hydrometric study [Bonell and Gilmour, 1978] established the importance of overland flow in the hydrological behavior of South Creek (Figure 1) and provided a rationale for saturation excess as generating mechanism [Bonell et al., 1981]. A subsequent hydrochemical investigation confirmed this importance by demonstrating the chemical similarity between storm flow and overland flow [Elsenbeer et al., 1994]. With respect to the application of mixing models in this tropical rain forest environment, the results of these two studies suggested that (1) overland flow should explicitly be considered one of the sources and (2) overland flow might be a mixture of preevent and event water depending on the degree of incision of individual flow lines and on hydrometeorological event characteristics. The application of mixing models presented in this paper is based on these premises. 


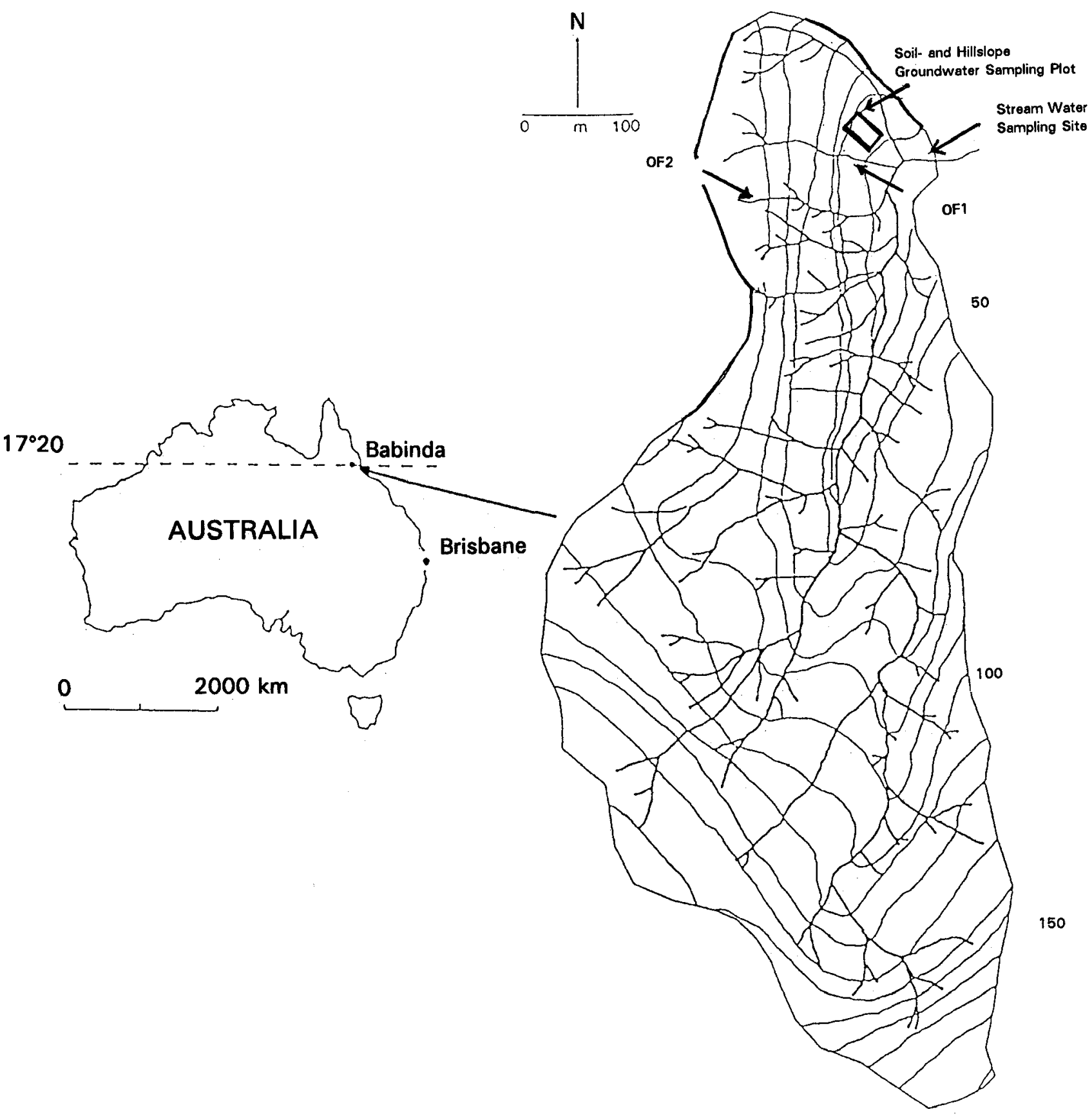

Figure 1. South Creek catchment: location map and sampling sites. OF1 and OF2 refer to overland flow sampling sites 1 and 2, respectively. OF1 represents an incised concentrated-flow line, OF2 is a flow line without defined channel.

\section{Site Description}

The South Creek catchment is located at $17^{\circ} 20^{\prime} \mathrm{S}$ and $145^{\circ} 58^{\prime} \mathrm{E}$ in the Graham range near the Queensland coast (Figure 1); its area is 25.7 ha, ranging in elevation from about $25 \mathrm{~m}$ to $190 \mathrm{~m}$ above mean sea level. The 1985-1992 mean annual precipitation at Babinda, about $5 \mathrm{~km}$ west of the catchment, is $4241 \mathrm{~mm}$; the mean and the 1993 February precipitation are $733 \mathrm{~mm}$ and $540 \mathrm{~mm}$, respectively. The dense drainage network (Figure 1) consists mainly of concentrated-flow lines, in the form of gullies, rills, or flow lines without a defined channel, active only in response to rainfall events. Very few gullies are intermittent, maintaining flow during the wet and early dry season. The steep side slopes are covered by Inceptisols, and Oxisols prevail on the small interfluve areas. The bedrock is composed of amphibolite; orthoamphibolite outcrops consist of andesine, sodic aluminous hornblende, quartz, chromium-rich chlorite, actinolite, epidote, and some opaques. The whole catchment is covered by cyclone-disturbed rain forest which is classified as mesophyll vine forest [Webb, 1968]. Information on soil physical properties, vegetation, hydrology, and climatology has been summarized by Bonell et al. [1991] and Bonell and Balek [1993]. 
Table 1. Precipitation Characteristics of the Events of February 18 and 23, 1993.

\begin{tabular}{lcr}
\hline \multicolumn{1}{c}{ Variable } & Event 1 & Event 2 \\
\hline Magnitude, mm & 177.7 & 44.2 \\
Duration, hours & 18.1 & 3.0 \\
$l_{6} \mathrm{max},{ }^{*} \mathrm{~mm} / \mathrm{h}$ & 90.0 & 63.0 \\
$l_{10} \mathrm{max}, \mathrm{mm} / \mathrm{h}$ & 79.8 & 60.0 \\
$l_{30} \mathrm{max}, \mathrm{mm} / \mathrm{h}$ & 57.6 & 45.0 \\
$l_{60} \mathrm{max}, \mathrm{mm} / \mathrm{h}$ & 50.7 & 27.8 \\
$l_{120} \mathrm{max}, \mathrm{mm} / \mathrm{h}$ & 45.5 & 17.5 \\
\hline
\end{tabular}

*These are maximum intensities, with the subscripts referring to the time period in minutes over which they were evaluated.

\section{Methods}

Sampling strategies regarding streamflow and overland flow, sample handling, analytical procedures, and the storm flow behavior of a number of tracers are described by Elsenbeer et al. [1994]. Briefly, streamflow and overland flow at site 1 (OF1 in Figure 1) were sampled simultaneously at short time intervals during two precipitation events in February 1993 (for details see Table 1); in addition, two overland flow samples per event were taken at site 2 (OF2 in Figure 1). Both overland flow sampling sites represent concentrated-flow lines; while $\mathrm{OF} 1$ is a flow line incised along portions of its thalweg, OF2 is not. This distinction is essential: We assumed that $\mathrm{OF} 2$ represents saturation overland flow (SOF) of a constant chemical composition relative to that of OF1. Other potential endmembers that were sampled at fixed time intervals, as well as just before and immediately after events, were soil water by means of suction lysimeters at three sites within the instrumented plot (Figure 1) from the depths of $0.3,0.6$, and $1.2 \mathrm{~m}$, and hillslope groundwater from a depth of 2-4 $\mathrm{m}$ at three sites in the same plot.

We selected potassium (K) and acid-neutralizing capacity (ANC) as tracers for the following analysis because this combination provides the best separation of sources in twodimensional mixing plots (Figures 3, 4, and 5). As was shown for a similar geoecosystem (H. Elsenbeer et al., Chemical fingerprints of hydrological compartments and flow paths at La Cuenca, western Amazonia, submitted to Water Resources Research, 1995; hereinafter Elsenbeer et al., submitted manuscript, 1995), a prominent $\mathrm{K}$ signal characterizes near-surface sources and near-surface fast flow paths, while subsurface sources and associated slow flow paths have low K concentrations. The reverse argument applies to ANC that is furthermore considered conservative; it is calculated as the difference in concentrations between "strong" cations (calcium, magnesium, sodium, and potassium) and "strong" anions (sulfate, chloride). The behavior of these two tracers in stream and overland flow during the two events is shown in Figure 2.

For the three-component mixing models considered here, the contributions of the components are calculated as fractions by solving

$$
\begin{gathered}
f_{1}+f_{2}+f_{3}=1 \\
{[\mathrm{~K}]_{1} f_{1}+[\mathrm{K}]_{2} f_{2}+[\mathrm{K}]_{3} f_{3}=[\mathrm{K}]_{s, o f}} \\
\mathrm{ANC}_{1} f_{1}+\mathrm{ANC}_{2} f_{2}+\mathrm{ANC}_{3} f_{3}=\mathrm{ANC}_{s, o f}
\end{gathered}
$$

where $f$ is the fraction of each component contributing to streamflow (subscript $s$ ) or overland flow (subscript of ), $[\mathrm{K}]$ is the potassium concentration, ANC the acid neutralization ca- pacity; and the subscripts 1,2 , and 3 refer to the three components. The equations were solved for each time a stream water and overland flow sample was taken.

\section{Results \\ Choice of End-Members}

Figure 3 and Table 2 give a general picture of the South Creek watershed chemistry during the study period for $\mathrm{K}$ and ANC. Streamflow observations tend to follow a line from an end-member of low $\mathrm{K}$ and high $\mathrm{ANC}$, approximated by hillslope groundwater ( $\mathrm{HGW}$ ), to an end-member high in $\mathrm{K}$ and low in ANC. Although overland flow from site 2 (OF2) is the end-member with the highest $\mathrm{K}$ and lowest ANC median values, streamflow samples near peak discharge are even higher in $\mathrm{K}$. The soil water sources are rather removed from the bulk of stream water observations. The overland flow samples collected at site 1 follow generally the trend of stream water samples, with the notable exception of a small cluster labeled "flushing effect." These observations are associated with the onset of overland flow during event 1 . Figures 4 and 5 depict the event and immediate preevent watershed chemistry for events 1 and 2, respectively. A triangle formed by HGW, SW60, and OF2 contains hardly any event 1 stream water observations (Figure 4). The end-member saturation overland flow is obviously poorly characterized because it is too low in $\mathrm{K}$. We argue that the potassium chemograph peak during event 1 (Figure $2 \mathrm{~g}$ ) can only be produced by overland flow, because there is no other source of potassium. Hence we assume that the $\mathrm{K}$ concentration of saturation overland flow (OF2) must be at least as high as the highest $\mathrm{K}$ concentration during storm flow. A triangle formed by HGW, SW60, and such an idealized overland flow end-member $\left(\mathrm{Of}_{\mathrm{id}}\right)$ based on the highest storm flow $\mathrm{K}$ concentration encompasses nearly all stream water and overland flow (from site 1) samples (Figure 4). The choice of soil water source does not appear to be too critical. For event 2 (Figure 5) the sources HGW, SW60, and OF2 encompass the majority of storm flow and all overland flow (OF1) observations. If we include the idealized overland flow end-member $O f_{i d}$, the triangle contains all observations. Again, the soil depth hardly changes the shape and position of the triangle. Considering Figures 4 and 5, we select, for the prior modeling exercise, the contributing sources HGW, SW60, and saturation overland flow, represented by both OF2 and $\mathrm{OF}_{\mathrm{id}}$.

\section{Chemical Nature of Overland Flow}

The temporal variation of overland flow (OF1, incised flow path) chemistry (Figures 2a, 2b, 2e, and 2f) and the spread of the corresponding observations in Figures 4 and 5 suggest that the chemical composition of this fast pathway is controlled by the same sources that were identified above. Their contributions to overland flow (OF1), expressed as fractions, throughout the two events are shown in Figures $6 a$ and $6 \mathrm{~b}$, and $7 \mathrm{a}$ and $7 \mathrm{~b}$, respectively. The two top panels (Figures $6 \mathrm{a}$ and $7 \mathrm{a}$ ) show the modeling results with the measured composition of saturation overland flow (OF2); the two middle panels (Figures $6 \mathrm{~b}$ and $7 b$ ) are based on the inferred composition of this endmember $\left(\mathrm{Of}_{\mathrm{id}}\right)$ as discussed above. For event 1 the inadequate characterization of the end-member saturation overland flow (OF2) yields, not unexpectedly, physically impossible results which are exacerbated early in the event by the flushing effect (see Figures $2 \mathrm{a}$ and 4 ). The modeling results based on the 
a)

EVENT 1

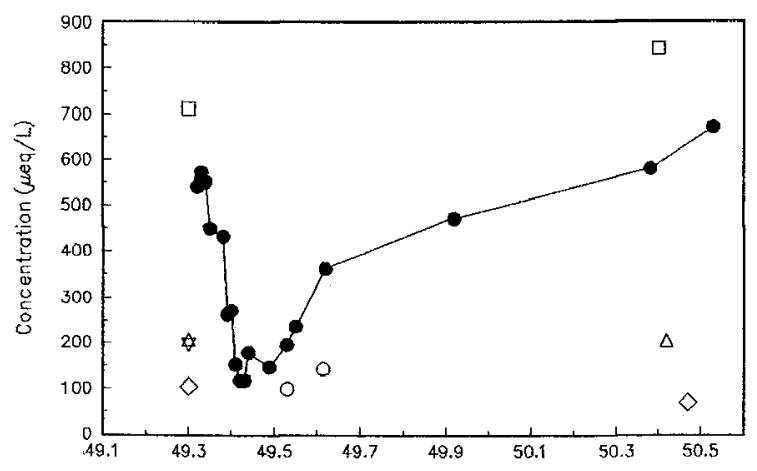

c)

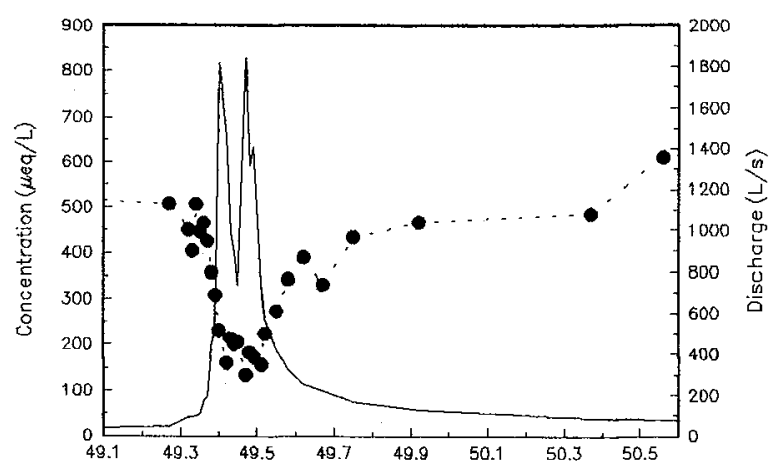

e)

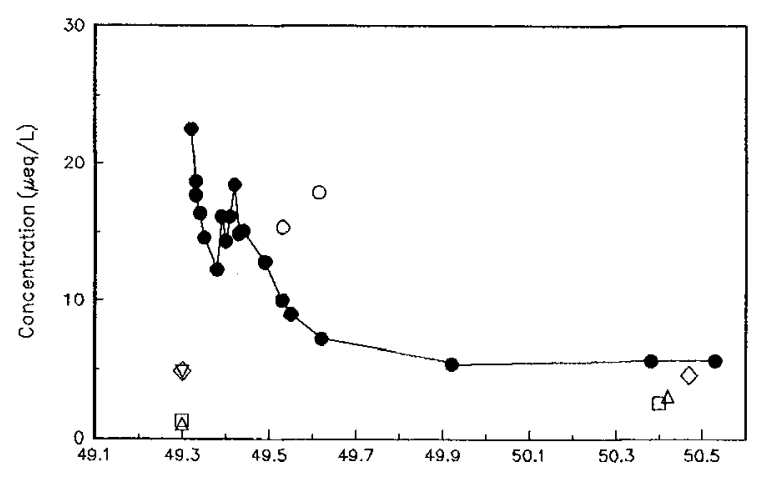

g)

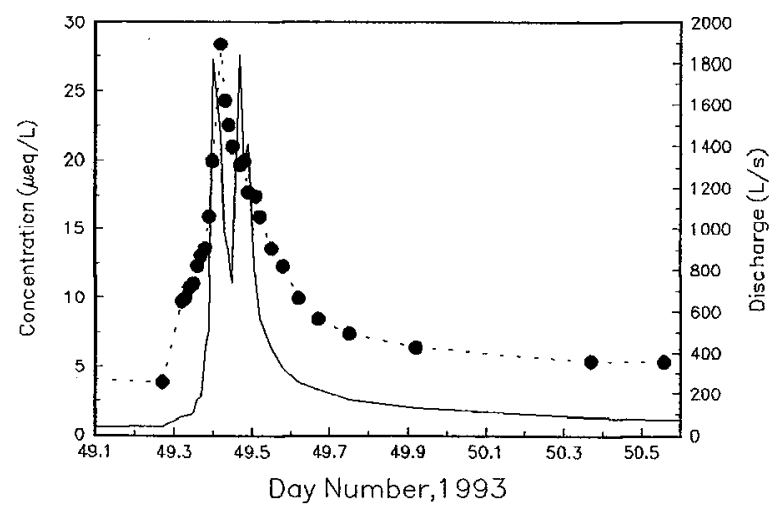

b)

EVENT 2

Overland Flow

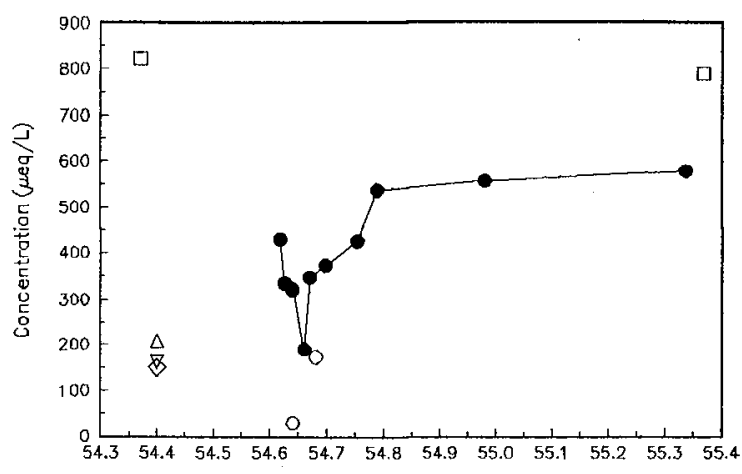

d)

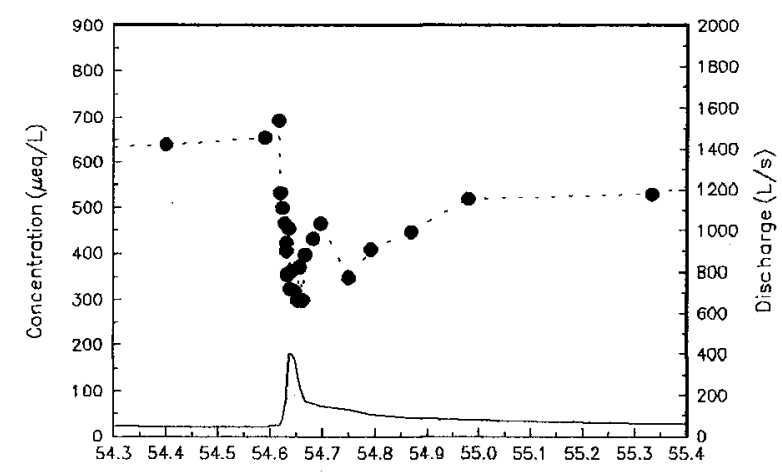

f)

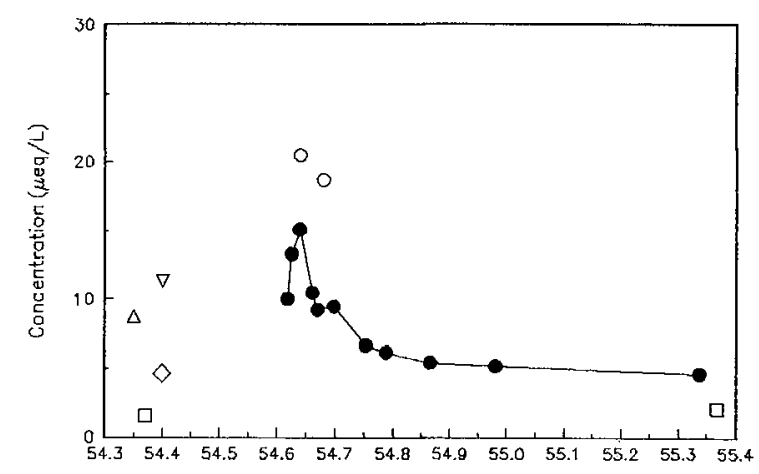

h)

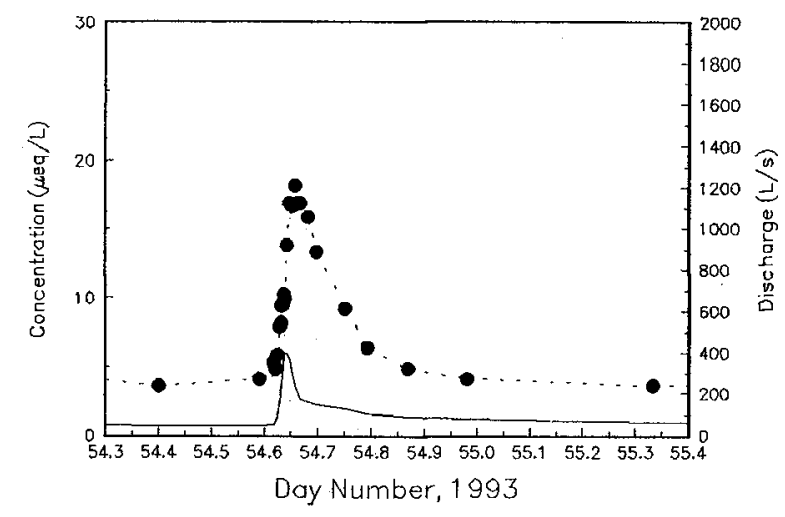

Figure 2. Storm flow and overland flow chemographs of event 1 (left panels) and event 2 (right panels): (a-d) acid-neutralizing capacity; (e-h) potassium. Solid line denotes discharge; open circles denote observations from site OF2; squares denote hillslope groundwater (HGW); and triangles, diamonds, reverse triangles denote soil water from depths 1.2 (SW120), 0.6 (SW60), and $0.3 \mathrm{~m}$ (SW30), respectively. 


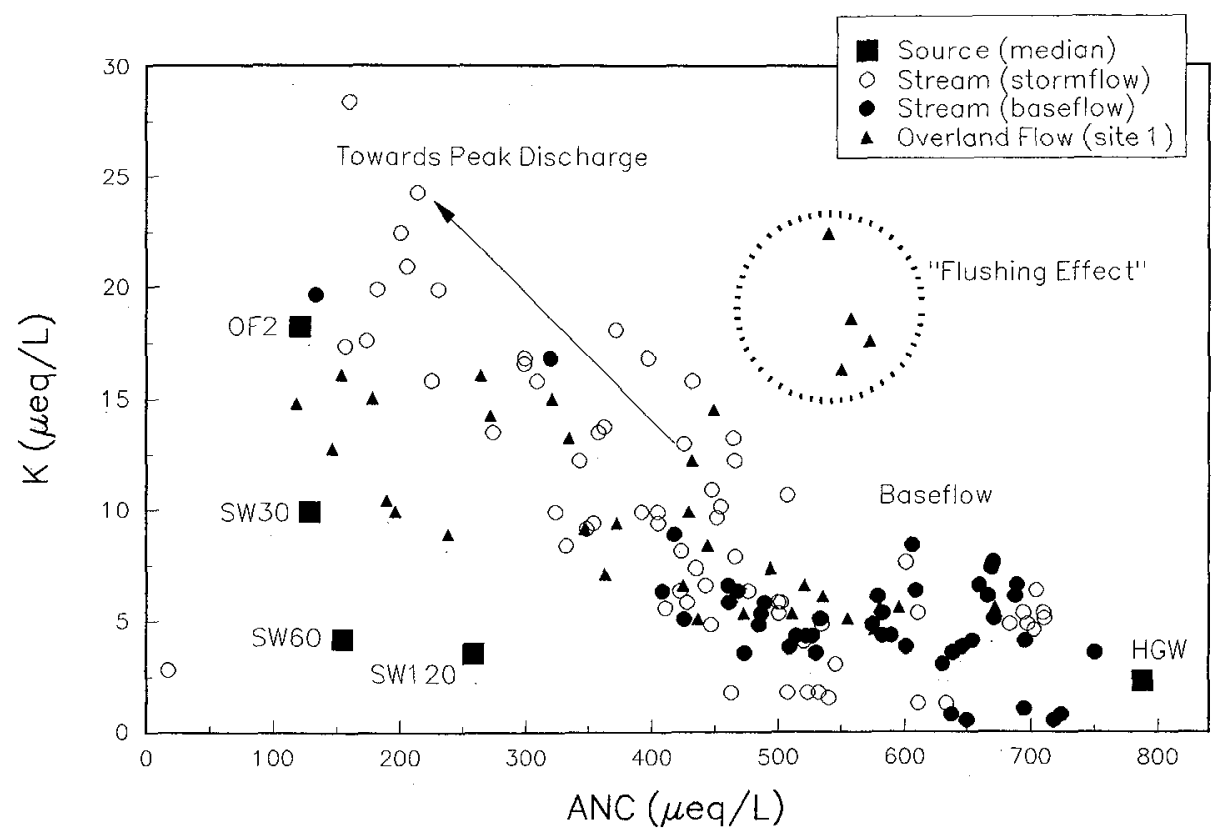

Figure 3. K-ANC mixing plot of all watershed chemistry data collected from January 27 to February 25 , 1993. The sources ("end-members"), expressed as the median of all observations, are hillslope groundwater (HGW), soil water from depths 1.2 (SW120), 0.6 (SW60), and $0.3 \mathrm{~m}$ (SW30), and saturation overland flow (OF2). The confidence limits for the medians are given in Table 2, except for OF2 whose $\mathrm{K}$ and ANC concentrations range from 15 to $21 \mu \mathrm{eq} / \mathrm{L}$ and from 30 to $170 \mu \mathrm{eq} / \mathrm{L}$, respectively.

inferred "idealized" saturation overland flow composition $\left(\mathrm{Of}_{\mathrm{id}}\right)$ are shown in the middle panel of Figure 6. Although the flushing effect distorts the fractions in the beginning of the event, resulting in an unreasonable hillslope groundwater contribution, a clear pattern emerges subsequently: The initially high fraction of SOF decreases gradually, while the hillslope groundwater contribution to overland flow increases from 0 for $40 \%$ toward the end of the event. The soil water contribution reaches a maximum of $60 \%$ when the contribution of both HGW and SOF are low, before dropping off to the same level as HGW. For event 2 the representation of saturation overland flow by OF2 (Figure 7a) yields an initially high fraction of this end-member that then decreases rapidly. The contribution of hillsiope groundwater increases gradually, while that of soil water passes through a maximum. The use of the inferred SOF end-member $\left(\mathrm{Of}_{\mathrm{id}}\right)$ yields the same pattern, but a much higher contribution of soil water at the expense of saturation overland flow.
In summary, regardless of the precise composition of saturation overland flow, the fast pathway overland flow along incised concentrated-flow lines, such as rills and gullies, apparently transmits a mixture of event water, i.e., saturation overland flow that obtains its chemical signature at the soil surface, and preevent water, i.e., soil water and hillslope groundwater, whose proportions change consistently through the event. As evidenced by event 2 (Figures $7 \mathrm{a}$ and $7 \mathrm{~b}$ ), the proportions are sensitive to the uncertainty in the composition of the SOF end-member.

\section{Sources of Storm Flow}

The bottom panels of Figures 6 and 7 show the contributions of hillslope groundwater, soil water, and saturation overland flow to streamflow during events 1 and 2, respectively. The choice of end-members is based on the respective mixing plots (Figures 4 and 5 ), and SOF is represented by its inferred composition, $\mathrm{Of}_{\mathrm{id}}$, as explained above. During event 1 (Figure

Table 2. The Median Concentrations of $\mathrm{K}$ and ANC in Soil Water and Groundwater and Their 95\% Confidence Limits

\begin{tabular}{|c|c|c|c|c|c|c|}
\hline \multirow[b]{2}{*}{ Source } & \multicolumn{3}{|c|}{ K } & \multicolumn{3}{|c|}{ ANC } \\
\hline & Lower Limit & Median & Upper Limit & Lower Limit & Median & Upper Limit \\
\hline $\begin{array}{l}\text { Hillslope groundwater } \\
(n=65)\end{array}$ & 1.9 & 2.3 & 2.9 & 753 & 788 & 832 \\
\hline $\begin{array}{l}\text { Soil water, } 1.2 \mathrm{~m} \text { depth } \\
\quad(n=41)\end{array}$ & 2.5 & 3.6 & 4.7 & 196 & 258 & 321 \\
\hline $\begin{array}{l}\text { Soil water, } 0.6 \mathrm{~m} \text { depth } \\
\quad(n=13)\end{array}$ & 0.5 & 3.8 & 7.2 & 131 & 167 & 202 \\
\hline $\begin{array}{l}\text { Soil water, } 0.3 \mathrm{~m} \text { depth } \\
\quad(n=16)\end{array}$ & 3.5 & 8.2 & 12.9 & 72 & 143 & 214 \\
\hline
\end{tabular}

Data are in microequivalents per liter. 


\section{EVENT 1}

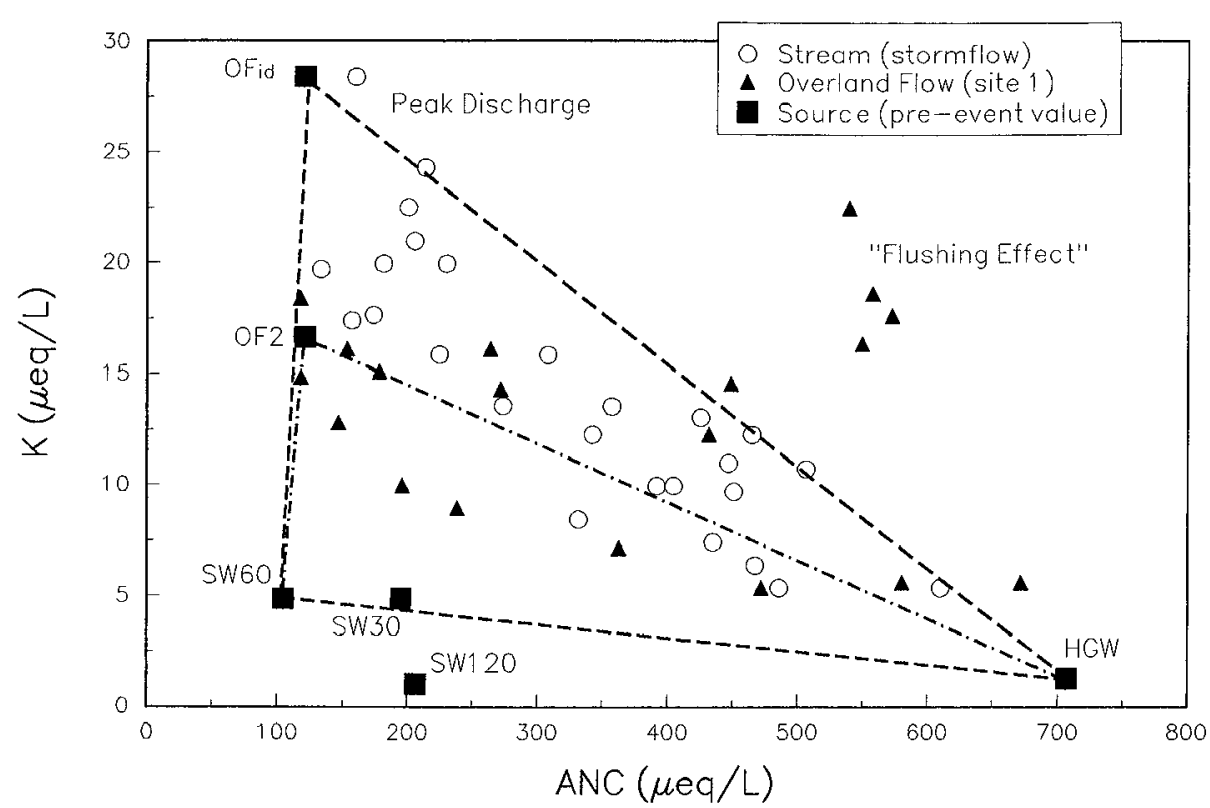

Figure 4. K-ANC mixing plot for event 1 (February 18, 1993). The sources ("end-members"), expressed as the median of three sites, are hillslope groundwater (HGW) and soil water from depths 1.2 (SW120), 0.6 (SW60), and $0.3 \mathrm{~m}$ (SW30); saturation overland flow is the mean of two observations (see also Figures 2a and $2 \mathrm{e}),(\mathrm{OF} 2)$, or the deduced concentration $\left(\mathrm{Of}_{\mathrm{id}}\right.$, see also text); accordingly, there are two mixing regions.

6c) the contribution of SOF reaches almost $80 \%$ near peak flow, at which time the groundwater contribution nearly vanishes. The crossover pattern of SOF and HGW is similar to overland flow at OF1 (Figure 6b). The soil water contribution reaches a maximum of nearly $40 \%$ halfway on the recession limb and is almost equal to the groundwater contribution at the end of the event.

In contrast, the contribution of SOF does not exceed $60 \%$

\section{EVENT 2}

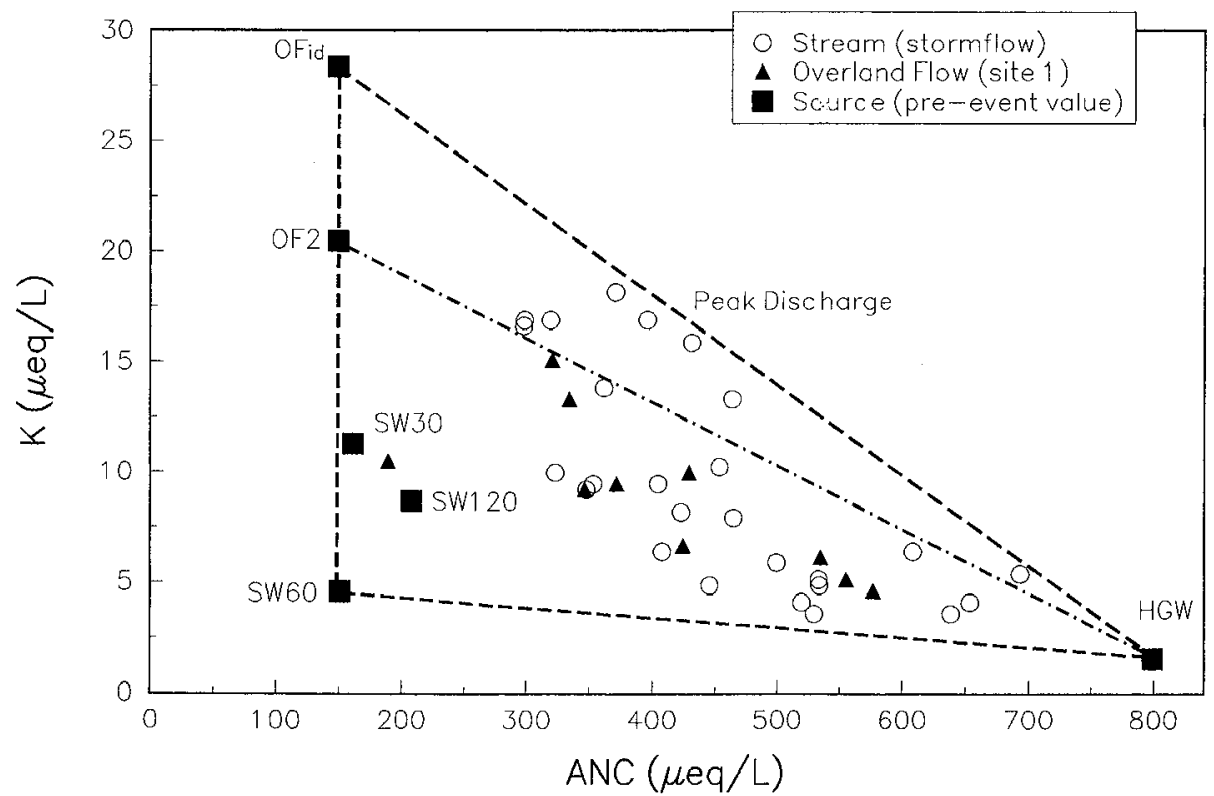

Figure 5. K-ANC mixing plot for event 2 (February 23, 1993). The sources ("end-members"), expressed as the median of three sites, are hillslope groundwater (HGW) and soil water from depths 1.2 (SW120), 0.6 (SW60), and $0.3 \mathrm{~m}$ (SW30); saturation overland flow is the mean of two observations (see also Figures 2a and 2e), (OF2), or the deduced concentration $\left(\mathrm{Of}_{\mathrm{id}}\right.$, see also text); accordingly, there are two mixing regions. 
a)

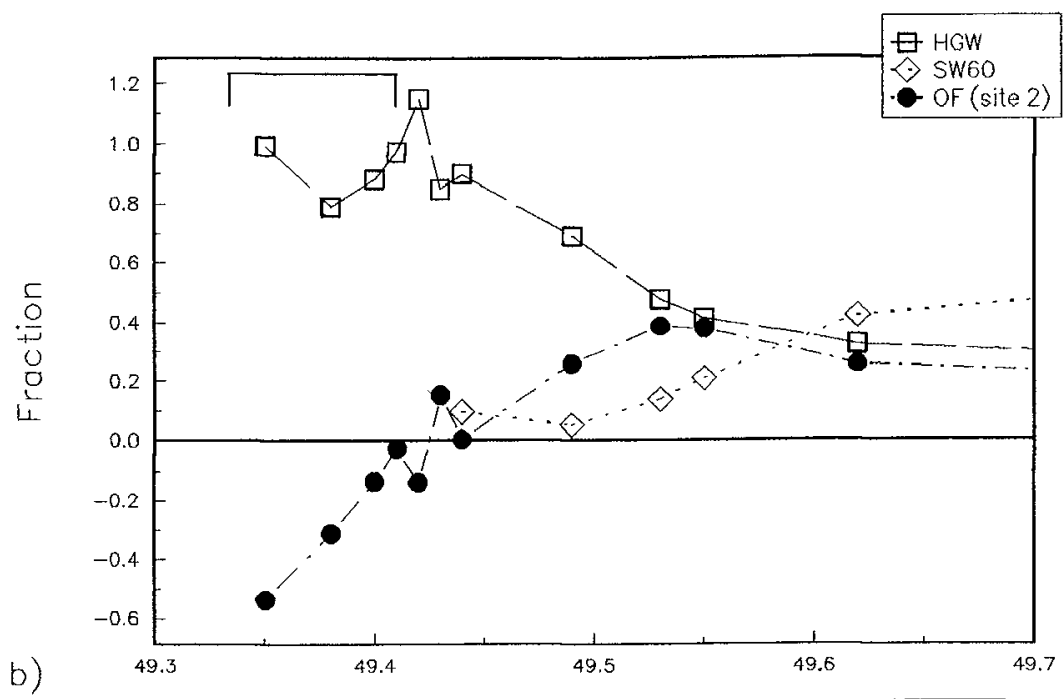

b)
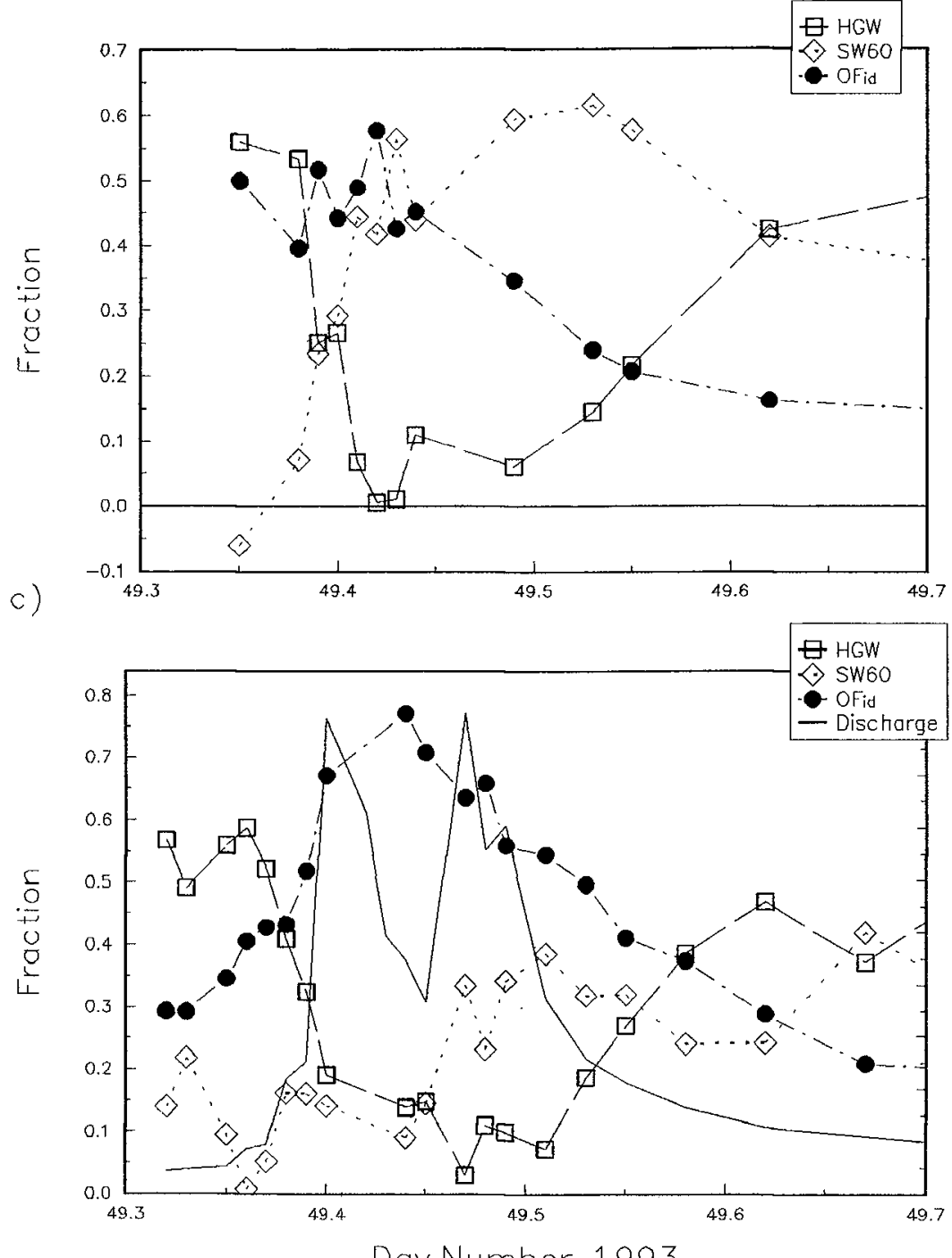

Day Number, 1993

Figure 6. The time-dependent contribution of sources, expressed as fraction of overland flow and streamflow, respectively, for event 1. (a) Overland flow, with OF (site 2) (see Figure 4) representing saturation overland flow. (b) Overland flow, with $\mathrm{Of}_{\mathrm{id}}$ representing saturation overland flow. (c) Streamflow. 
a)

b)
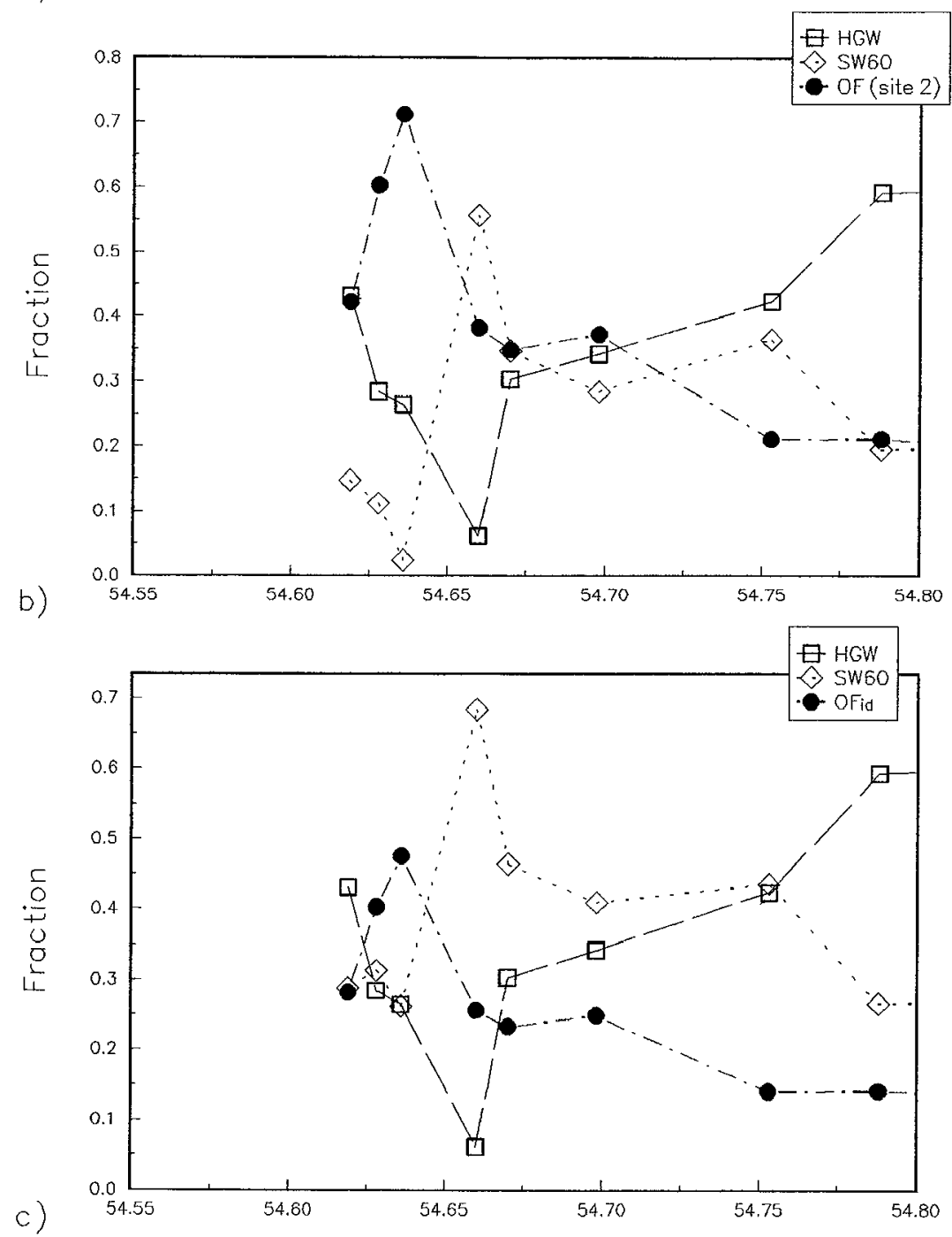

c)

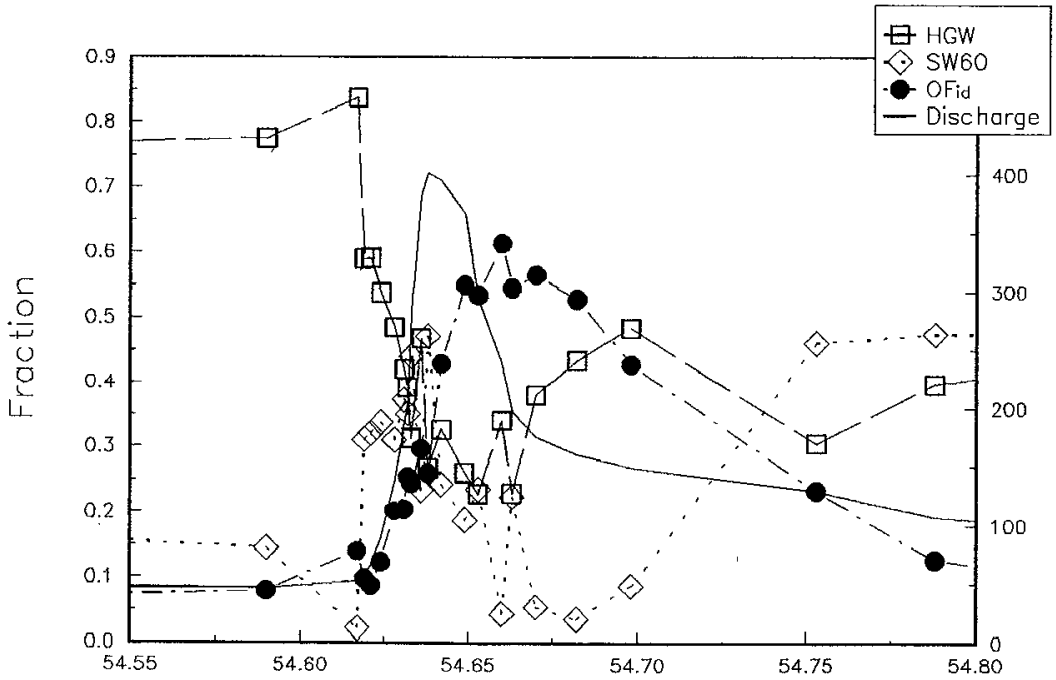

Day Number, 1993

Figure 7. The time-dependent contribution of sources, expressed as fraction of overland flow and streamflow, respectively, for event 2. (a) Overland flow, with OF (site 2) (see Figure 4) representing saturation overland flow. (b) Overland flow, with $\mathrm{Of}_{\mathrm{id}}$ representing saturation overland flow. (c) Streamflow. 


\section{EVENT 1}

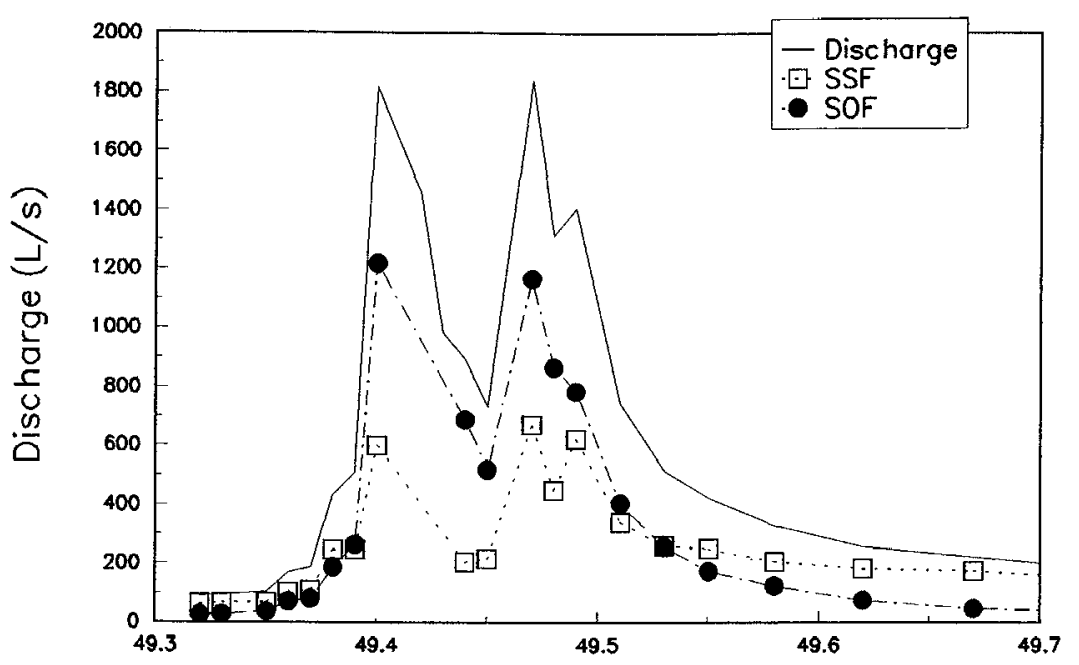

\section{EVENT 2}

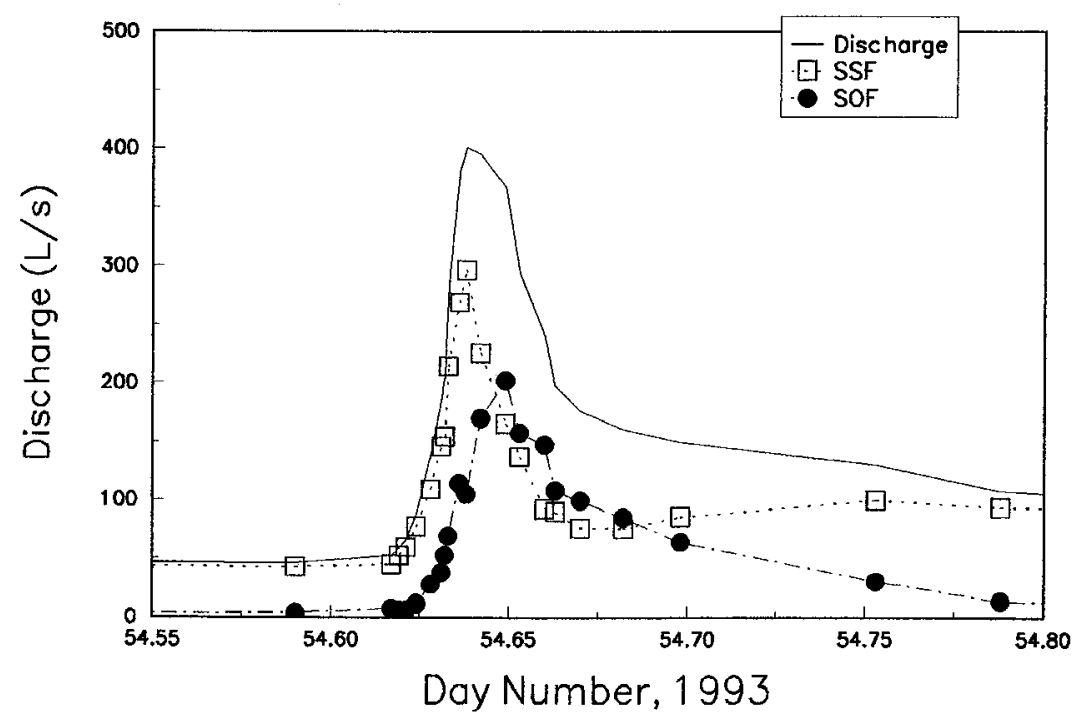

Figure 8. The contributions of event water (saturation overland flow, SOF) and preevent water (subsurface flow from vadose and saturated zone, SSF) to streamflow during (top) event 1 and (bottom) event 2.

during event 2 (Figure 7c), and that of HGW does not fall below $25 \%$. The soil water contribution is very pronounced on the rising limb, reaching 50\%, but, unlike in event 1 (Figure $6 \mathrm{c}$ ), decreases during the hydrograph recession. Toward the end of both the events, the contributions of SW60 and HGW are similar.

\section{Preevent and Event Water Contributions to Storm Flow}

The preceding analysis demonstrates that overland flow, as sampled from an incised flow line such as OF1, consists of event and preevent water; hence, the simple equation "fast flow path equals event water" does not hold in this environment. It is necessary to distinguish between unincised and incised fast flow paths, to distinguish between overland flow that is generated at the soil surface during the event, i.e., SOF, and overland flow that represents various sources. Only SOF can be considered event water. If we pool the hillslope groundwater and soil water contributions (Figures $6 \mathrm{c}$ and $7 \mathrm{c}$ ) as subsurface flow of preevent water, a separation in event (SOF) and preevent water (SSF) is possible. For event 1 with its sustained high rainfall intensity (see Table 1), event water (SOF) dominates the hydrograph (Figure 8, top). The shortduration, low-intensity, 44.2 -mm event 2 , only 5 days after the $177.7-\mathrm{mm}$ event 1 , resulted in a much smaller event water (SOF) contribution (Figure 8, bottom). The separation for event 2 also suggests that preevent subsurface sources were mobilized quickly to contribute to the rising limb of the storm 
flow hydrograph through overland flow in rills and gullies. Unlike in event 1 , event water exceeds preevent water during a short period only, and then only by a small margin.

\section{Discussion}

The mixing plots, Figures 3 and 4 in particular, clearly illustrate the problems of applying the mixing model approach to a fast flow path-controlled catchment. As pointed out above, this approach is used to infer pathways, and hence does not rely on an a priori hydrologic study. Assume, then, that $\mathrm{OF} 2$ had not been sampled: In this case a mixing region could not have been established, nor could one have postulated a twocomponent model because the soil water sources are not in line with the stream water observations. Indeed, these observations call for a source high in $\mathrm{K}$ and low in ANC. A potential source meeting this requirement is obviously throughfall, and this would be the obvious choice if overland flow were not known as a flow path. We do know, however, from the studies cited previously that overland flow plays an important role in this catchment, and we know from a similar environment (Elsenbeer et al., submitted manuscript, 1995) that the chemical composition of throughfall is further modified by the soil surface, that is, overland flow and throughfall are chemically distinct. In particular, overland flow is enriched in $\mathrm{K}$ with respect to throughfall (Elsenbeer et al., submitted manuscript, 1995). For this reason we treated overland flow generated at the soil surface, as opposed to overland flow in incised pathways, as a source. For the same reason we inferred that the highest storm flow K concentration in South Creek (Figures $2 g$ and 4) must be attributed to overland flow. A spatially variable $\mathrm{K}$ concentration in overland flow is understandable in view of the patchy distribution of leaf litter: Thick layers alternate with extensive bare areas. In hindsight, more overland flow samples from unincised flow lines should have been taken to characterize the spatial variability of this source. Because of this variability the geometry of the mixing triangle should not be considered fixed [Bazemore et al., 1994, p. 67].

The question arises if the mixing region for event 1 (Figure 4 ) is not best defined by hillslope groundwater and the (yet unknown) spatial variability of SOF chemical composition; this possibility amounts to a two-component mixing model without a soil water contribution. A soil water source is required to define a mixing region for event 2 , though, which suggests that the contribution of soil water may depend on the catchment's antecedent moisture content: While event 1 was preceded by a dry period of nearly 2 weeks, only 5 days passed between event 1 and event 2. For the average north Queensland wet season, permanent near-saturation is the more likely scenario; that is why a soil water source should be included. Figures 4 and 5 raise the question of precisely what soil water compartments to consider. Inceptisols do not show a strong chemical zonation, so neither does the soil water composition, except for $\mathrm{K}$ (see Figures 3, 4, and 5). To see whether the choice of soil water end-member really mattered, we repeated the mixing analysis for stream flow (see Figure 6c) with SW30 and SW120. The results were hardly distinguishable from Figure $6 \mathrm{c}$; that is, the fraction of soil water contributing to storm flow is approximately the same regardless of depth. This result suggests that either the whole vadose zone contributes to storm flow, or the mixing analysis alone does not provide sufficient information about contributing sources.

As was the case with SOF as a source of storm flow, inde- pendent hydrometric information provides a clue as to which soil water source is more likely to contribute to storm flow. The investigation by Bonell and Gilmour [1978, Table II] included three sites with continuous monitoring of subsurface flow at depths of $0.25,0.5$, and $1 \mathrm{~m}$. While the volumes from 0.5 and $1 \mathrm{~m}$ were either zero or minimal, the flow at $0.25 \mathrm{~m}$ was substantial, and in a few cases approached or even exceeded the volume of overland flow at the same site. Although the sites of the 1978 study are not within our monitoring plot, these results implicate our component SW30 as a source of storm flow. Bonell and Gilmour [1978] also provide a rationale for the observed subsurface storm flow. In a separate analysis, however, using deuterium and hillslope hydrometric data, Bonell et al. [1995] identified up to five sources contributing to storm flow, including those identified in this study. It appears that the inclusion of more than three end-members cannot be supported by mixing analyses owing to the weak differentiation between soil water end-members. Under such circumstances, physically based sources might be more useful than sources derived from a mixing analysis; at least, additional, hydrometric data should be included before selecting end-members for modeling purposes. The analysis of a large number of storms, however, may yield different soil water sources for different storms.

Regardless of the precise source of soil water, our results provide further evidence for the role of preevent soil water in storm flow generation of forested catchments. This role has already been documented by Mulholland [1993, Figure 8] for Walker Branch, and by Bazemore et al. [1994, Figures 6 and 7] for Shaver Hollow. Although the three environments differ with respect to the relative importance of preevent soil water for storm flow generation, it is worthwhile comparing event 2 (Figure 7c), with its moderate, almost "temperate" rainfall intensities, with the June 1992 event of Bazemore et al. [1994, Figure 6A] and the March 1991 event of Mulholland [1993, Figure 8]: Given the uncertainty of these estimates, as demonstrated by Bazemore et al. [1994], the fraction of soil water contributing to peak flow at South Creek of nearly $50 \%$ is probably not significantly different from the $65 \%$ reported for Shaver Hollow [Bazemore et al., 1994, p. 66] and is practically identical to Walker Branch [Mulholland, 1993, Figure 8b]. As shown by event 1 (Figure $6 \mathrm{c}$ ), precipitation characteristics clearly determine the proportions of contributing sources, and it is the hydrometeorology that sets apart northeast Queensland and the southeastern United States. Nonetheless, a detailed comparison of the three sites might reveal more common ground concerning hydrological processes than the geographical differences suggest.

\section{Conclusions}

Soil water and groundwater sources alone cannot explain the observed storm flow chemistry in this overland flowdominated catchment. Hence the correct hydrological pathways cannot be inferred from the storm flow hydrochemical signal alone. We suggest that overland flow be considered a true source of storm flow wherever it can be assumed to be generated at the soil surface itself, i.e., where its flow lines are not incised. In the latter case, overland flow was shown to be a mixture of subsurface and surface sources, or preevent and event water. Hence in this environment the fast pathway overland flow may transmit preevent or event water. Accordingly, a substantial portion of the storm flow hydrograph can be attrib- 
uted to preevent water from subsurface sources, depending on event characteristics and antecedent moisture conditions. Preevent water sources are hillslope groundwater and soil water. The poorly developed chemical zonation of Inceptisols restricts the usefulness of the mixing analysis in identifying the precise source of soil water, although independent hydrometric information implicates a shallow soil layer. The contribution of preevent soil water to the storm flow hydrograph during a low-intensity event is similar to that of other forested headwater catchments, while the contribution of strictly event overland flow appears to be unique to tropical rain forest catchments.

We conclude that the successful application of mixing models to catchments characterized by fast pathways and/or chemically weakly differentiated soils requires the consideration of additional hydrometric information.

Acknowledgments. This project was funded by the Swiss National Science Foundation, grant 20-33590.92, which also provided support for Daniel Lorieri and Mike Bonell. Karin Bryant, Dagmar Riesen, and Adam West assisted in the collection and field analysis of water samples. Barry Butler and John Faithful (Australian Centre for Tropical Freshwater Research) generously supported our analytical efforts in the field. Clive Grant provided streamflow and precipitation data, Dagmar Riesen information on lithology. Special thanks to an anonymous reviewer who encouraged us to take a fresh look at the same old data; it was worth it!

\section{References}

Bazemore, D. E., K. N. Eshleman, and K. J. Hollenbeck, The role of soil water in stormflow generation in a forested headwater catchment: Synthesis of natural tracer and hydrometric evidence, $J$. $\mathrm{Hy}$ drol., 162, 47-75, 1994.

Beck, M. B., F. M. Kleissen, and H. S. Wheater, Identifying flow paths in models of surface water acidification, Rev. Geophys., 28(2), 207$230,1990$.

Bonell, M., and J. Balek, Recent scientific developments and research needs in hydrological processes of the humid tropics, in Hydrology and Water Management in the Humid Tropics, edited by M. Bonell, M. M. Hufschmidt, and J. S. Gladwell, pp. 167-260, Cambridge Univ. Press, New York, 1993.

Bonell, M., and D. A. Gilmour, The development of overland fiow in a tropical rainforest catchment, J. Hydrol., 39, 365-382, 1978.

Bonell, M., D. A. Gilmour, and D. F. Sinclair, Soil hydraulic properties and their effect on surface and subsurface water transfer in a tropical rainforest catchment, Hydrol. Sci. Bull., 26, 1-18, 1981.

Boneil, M., D. A. Gilmour, and D. S. Cassells, The links between synoptic climatology and the runoff response of rainforest catchments on the wet tropical coast of northeastern Queensland, in Australian National Rainforests-Study Report, vol. 2, edited by P. A. Kershaw and G. Werran, pp. 27-62, Aust. Heritage Comm., Canberra, 1991.

Bonell, M., C. R. Barnes, C. R. Grant, A. Howard, and J. Burns, High rainfall, response-dominated catchments: A comparative study of experiments in tropical northeast Queensland with temperate New Zealand, in Isotope Tracers in Catchment Hydrology, edited by J. J. McDonnell and C. Kendall, Elsevier, New York, in press, 1995.

Caine, N., Hydrograph separation in a small alpine basin based on inorganic solute concentrations, J. Hydrol., 112, 89-101, 1989.

Christophersen, N., C. Neal, R. P. Hooper, R. D. Vogt, and S. Andersen, Modeling streamwater chemistry as a mixture of soil water end-members-A step towards second generation acidification models, J. Hydrol., 116, 307-320, 1990.

Christophersen, N., C. Neal, and R. P. Hooper, Modelling the hydrochemistry of catchments: A challenge for the scientific method, $J$. Hydrol., 152, 1-12, 1993.

DeWalle, D. R., B. R. Swistock, and W. E. Sharpe, Three-component tracer model for stormflow on a small Appalachian forested catchment, J. Hydrol., 104, 301-310, 1988.

Elsenbeer, H., A. West, and M. Bonell, Hydrological pathways and stormflow hydrochemistry at South Creek, northeast Queensland, $J$. Hydrol, 162, 1-21, 1994.

Emmett, H. W., Overland flow, in Hillslope Hydrology, edited by M. J. Kirkby, pp. 145-176, John Wiley, New York, 1978.

Genereux, D. P., H. F. Hemond, and P. J. Mulholland, Use of radon222 and calcium as tracers in a three-end-member mixing model for streamflow generation on the West Fork of Walker Branch watershed, J. Hydrol., 142, 167-211, 1993.

Hendershot, W. H., S. Savoie, and F. Courchesne, Simulation of stream-water chemistry with soil solution and groundwater flow contributions, J. Hydrol., 136, 237-252, 1992.

Hinton, M. J., S. L. Schiff, and M. C. English, Examining the contributions of glacial till water to storm runoff using two- and threecomponent hydrograph separations, Water Resour. Res., 30(4), 983$993,1994$.

Hooper, R. P., and C. A. Shoemaker, A comparison of chemical and isotopic hydrograph separation, Water Resour. Res., 22(10), 1444$1454,1986$.

Hooper, R. P., N. Christophersen, and N. E. Peters, Modeling streamwater chemistry as a mixture of soil water end-members-An application to the Panola Mountain catchment, Georgia, USA, J. Hydrol, 116, 321-343, 1990.

McDonnell, J. J., A rationale for old water discharge through macropores in a steep, humid catchment, Water Resour. Res., 26(11), 28212832, 1990.

Moore, I. D., and G. F. Foster, Hydraulics and overland flow, in Process Studies in Hillslope Hydrology, edited by M. G. Anderson and T. P. Burt, pp. 215-254, John Wiley, New York, 1990.

Mulholland, P. J., Hydrometric and stream chemistry evidence of three storm flowpaths in Walker Branch watershed, J. Hydrol., 151, 291316, 1993.

Pinder, G. F., and J. F. Jones, Determination of the groundwater component of peak discharge from the chemistry of total runoff water, Water Resour. Res., 5(2), 438-445, 1969.

Pionke, H. B., W. J. Gburek, and G. J. Folmar, Quantifying stormflow components in a Pennsylvania watershed when $0-18$ input and storm conditions vary, J. Hydrol., 148, 169-187, 1993.

Webb, L. J., Environmental relationships of the structural types of Australian rainforest vegetation, Ecology, 49, 296-311, 1968.

Wels, C., J. Cornett, and B. LaZerte, Hydrograph separation: A comparison of geochemical and isotopic tracers, J. Hydrol., 122, 253-274, 1991.

Wilson, G. V., P. M. Jardine, R. J. Luxmoore, and J. R. Jones, Hydrology of a forested watershed during storm events, Geoderma, 46, 119-138, 1990.

Wilson, G. V., P. M. Jardine, R. J. Luxmoore, L. W. Zelazny, and D. E. Todd, Hydrogeochemical processes controlling subsurface transport form an upper Walker Branch watershed during storm events, 1, Hydrologic transport processes, J. Hydrol., 123, 297-316, 1991.

M. Bonell, Humid Tropics Program, UNESCO, 1, rue Miollis, 75732 Paris, France.

H. Elsenbeer and D. Lorieri, Institute of Geography, University of Berne, Hallerstrasse 12, 3012 Bern, Switzerland.

(Received February 6, 1995; revised April 28, 1995;

accepted May 24, 1995.) 